\title{
STUDENTS' COLLABORATION FOR ACTIVE LEARNING IN VOCATIONAL EDUCATION AND TRAINING IN INDONESIA THROUGH APPRENTICESHIP
}

\author{
Adi Maulana*, Jianjun Gu, Qiuyue Yang \\ Nanjing Normal University \\ *amp_aflah@yahoo.com
}

\begin{abstract}
This research aims to explain collaboration for active learning of vocational students through apprenticeships in West Java province. This program is to support Indonesia government program to revitalize vocational education following Presidential Instruction to improve human development index in Indonesia. This research involves 520 students taking an apprenticeship in grade 11 from several vocational schools in West Java Province. The participating schools were purposely selected by the first professional certification institution who conducted the field research through a questionnaire. The results show within the statistics descriptive of five indicators, which are student collaboration for active learning in apprenticeship appeared to be working together, obeying the general rule, good speaking skill, respect and professionalism with positive ethics is more $35 \%(\mathrm{n}=520)$. Collaboration is carried out by students from different schools. On the other hand, the role of the instructor is very helpful in apprenticeship. A possible explanation is that the finding of student collaboration using questionnaire answered for active learning in context vocational education and training has limitations to this research. It is indicated that further research is useful to be conducted by other researchers.
\end{abstract}

Keywords: Apprenticeship, Active Learning, Collaboration, Vocational school, West Java Province

Received 20 February 2020 Accepted 25 May 2020

\section{INTRODUCTION}

Indonesia is an archipelagic country with more than 17,508 registered islands, a somewhat strategic position in Southeast Asia with an archipelagic landscape of about 5,000 km from Irian Jaya to Aceh. In 2014, the population aged 15-64 was 252.2 million. The population density was estimated to be 131 people per square kilometer, with the largest population being on the island of Java. Indonesia Statistics Bureau reports a total labor force of 125.3 million in February 2014, of which 118.2 million were working, and 7.2 million (5.7\%) were unemployed [1]. According to the projected demographic bonus, or so-called demographic prizes, Indonesia will be acquired it in in 2020. See the figure below:

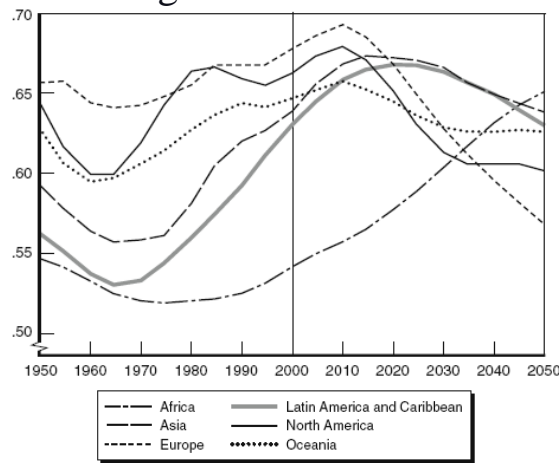

Figure 1. The window of opportunity in 2020 when the labor force up about $66 \%$ [2] 
Indonesia, with its large workforce and capacity as an ASEAN member country, signed a roadmap for the ASEAN community in 2009 in Jakarta. It was intended to prepare and improve the quality of human resources thoroughly, particularly in the education sector, which will prioritize educational adaptation, including vocational and technical education, as well as human resources as part of development investment in the ASEAN region. It includes assessments to identify gaps in training needs in ASEAN and the establishment of technical cooperation programs for labor.

The demographic bonus makes Indonesia the world's fourth-largest workforce, with the number standing at 127 million in the period 2020-2030. It is just crucial to prepare sufficient job opportunities to meet the high demand for it. Aligning with the ASEAN roadmap, the government of Indonesia has revitalized vocational high school (SMK) to improve the quality and competitiveness of Indonesian human resources [3]. By Presidential Instruction number 9 of 2016, the Minister of Education and Culture revitalizes vocational high school in six points. Two points are aiming at perfecting and aligning the vocational high school curriculum with the competence needed by the users of the graduates, i.e., industries (link and match). It also mandates the cooperation of the Ministry/ Institution, Government Region, and business/industry. There are three types of vocational education in Indonesia; they are Vocational Education, Work Training Center, and Polytechnic. The three education programs are intended for the improvement of vocational skills in preparing for work readiness. The highest priority is especially for vocational education, which takes 3-4 years of education in secondary schools. Indonesia is now faced with the fourth phase of the industrial revolution and cannot evade competition and globalization era, just like any other nation. The problem is real and close to Indonesia. As an illustration, in 2016, from 139 members countries of The World Economic Forum, Indonesia is included in the group of countries with lower middle income and has the following ratings [4].

Table 1. The World Economic Forum of Report

\begin{tabular}{cccc}
\hline No & $\begin{array}{c}\text { Index dan Sub } \\
\text { Indexmeasurement }\end{array}$ & Value & Rank \\
\hline 1 & $\begin{array}{c}\text { The Networked } \\
\text { Readiness Index } \\
\text { Environment (Political } \\
\text { and Innovation) }\end{array}$ & 4.0 & 73 \\
3 & $\begin{array}{c}\text { Readiness skills } \\
\text { Individual usage }\end{array}$ & 5.1 & 62 \\
4 & 3.3 & 65 \\
\hline
\end{tabular}

Looking at the table, Indonesia's position comparing with ASEAN countries in the index of skills readiness in the individual's role is still inferior to other countries. Take as an example of Singapore ranks number 1 for skills readiness and 12 for the individual role. Malaysia holds 46 ranks for skills readiness and 47 for individual roles. Indonesia's ranks in the World Economic Forum have become a challenge for the Indonesian workforce to compete with the workforce from other ASEAN countries.

ASEAN economic society has thoroughly written its preparation to improve the quality of its human resources, especially in education. Education will be one of its strengths. However, education may be its pitfalls if it conducted without proper management. In its plan, ASEAN has prioritized the adaptation of education, including vocational and technical training programs [5]. Cooperation between ASEAN countries is also observing the recognition of the same standards and opportunities to work freely among ASEAN countries [6] for eight professions: medical doctor, dentist, nurse, and architect, engineer (engineering), accountant, surveyor, and tour guide. Nonetheless, Indonesia's challenges are not only from the countries in the Southeast Asian region (ASEAN) with its Economic Community (MEA), which enables workers and vocational education graduates to find employment. Another challenge for Indonesia from other countries in the world is the development of the industrial revolution known as the 4th Industrial 
Revolution (the Industry 4.0) with the main character is the usage of cyber-physical systems or, in other words, the linkage of real objects and people with information-processing/virtual objects via information networks (Internet-of-things, 3D printing, artificial intelligence, bioengineering, cloud computing) as well as the use nanotechnologies and new efficient and intelligent materials [7]. In this digital era, the skill of information technology and communication, learning to learn, collaboration, and creativity are the competencies that need mastering as there will be abstract tasks with a significant decrease in both routine and manual tasks [8]. The fourth industrial revolution characterized by the reduction of manual labor (routine) replaced by machinery and information technology is two challenges that will be encountered by vocational education. Vocational education of Indonesia, primarily vocational high schools, was challenged to prepare the 4th industrial revolution, demography bonus, competition in ASEAN Economic Community, and labor market change.

To answer those challenges, Indonesian Government has A program to revitalize vocational high school (Revitalisasi SMK) through creating the roadmap for vocational high school involving business and industrial sectors, implementation of double system education through apprenticeship (industrial work practice), Link \& Match policy linking school and industry/business sector and teaching factory. The management of vocational education is based on four paradigms, with the target goal achieved in 2020 [9]. The paradigms are:

1 Educational orientation developed from supply-driven to demand-driven with the involvement of business and industry sector,

2 Change of educational management system from centralized becoming decentralized,

3 Change of paradigm from subject-based learning to computer-based learning,

4 More flexible and permeable school system.

Indonesia has 34 provinces, with a population of 258,705,000 in 2016. West Java province has the largest population with $47,379,400$ people or $18.31 \%$ of the total Indonesia population. According to the 2017 statistic, it can be seen that the working-age population, or above 15 years old, is 21,075,899 and 19,202,038 work [10]. West Java unquestionably has the largest workforce. West Java Province houses 2,845 vocational schools [11]. The ratio of teachers and students in vocational high schools in the province is one teacher for 23 students. The number of teachers is 42,984 and students 990,062 .

The following table shows the number of vocational schools in the island of Java which clearly shows how West Java outnumbers other provinces in vocational education:

Table 2. Vocational schools in Java

\begin{tabular}{cccc}
\hline \multicolumn{3}{c}{ Table 2. Vocational schools in Java } \\
Province & $\begin{array}{c}\text { Government } \\
\text { vocational } \\
\text { school }\end{array}$ & $\begin{array}{c}\text { Private } \\
\text { vocational } \\
\text { school }\end{array}$ & Total \\
\hline Jakarta & 63 & 516 & 579 \\
West Java & 277 & 2,568 & 2,845 \\
Banten & 75 & 595 & 670 \\
Central Java & 237 & 1332 & 1,569 \\
Yogyakarta & 50 & 168 & 218 \\
East Java & 293 & 1,680 & 1973 \\
\hline Total & $\mathbf{9 9 5}$ & $\mathbf{6 8 5 9}$ & $\mathbf{7 8 5 4}$ \\
\hline
\end{tabular}

Having the most significant population as well as the workforce and the number of vocational schools, West Java holds a strategic position as a model for other provinces. The success in West Java will be a significant influence on the national vocational education system. The revitalization roadmap for vocational high school will include implementation of learning innovations, standardization of facilities and infrastructure, institutional management, updating of industrial cooperation programs, teacher development program, and curriculum development and synchronization. All of them are meant to meet the $21 \mathrm{st}$-century skills or competence in the endeavor to increase vocational graduate employability. 
Vocational high schools have a motto, which is called SMK BISA-HEBAT, SIAP KERJA, SANTUN, MANDIRI, KREATIF (SMK SKILLFUL AND OUTSTANDING; READY TO WORK, GOOD-MANNERED, INDEPENDENT, AND CREATIVE). To live to this motto, the revitalization needs to include cooperation from industries and schools, curriculum development, and apprenticeship for students in vocational high school, which requires them to engage in nurturing the 21 st skills, especially soft skills. Besides soft skills, there is a technical skill (hard skill) which comprises quality-orientation, precision, measurability, consistency, work efficiency, and flexibility. According to The MoE regulation number 61/2013, about the conceptual benchmark of the 2013 curriculum, there are 13 points of development. Answering the future challenge, the 21 st skills to master are, among others, critical thinking, decision making, complex and cross-disciplinary problem solving, creative thinking, entrepreneurship, communication and collaboration, innovation, finance management, health, and civic responsibility. This research aims to explain collaboration for the active learning of vocational students through apprenticeships in West Java Province to support the Indonesia government program in revitalizing vocational high school to meet Presidential Instruction to improve the human development index in Indonesia.

\section{LITERATURE REVIEW}

\section{A. Apprenticeship on vocational high school in West Java, Indonesia}

The vocational high school in Indonesia emphasized that students have some competencies needed in the world of work [12]. This statement one purpose of vocational high school to establish. Students of vocational high school with an age average of 16-18 years still young but are entering the world of work is a symbolic division between being young and becoming an adult. So adolescents must be allowed to pursue vocational training or studies leading to a professional qualification. However, one problem can be seen that growing young people are having difficulty taking the critical step into the world of work or are denied the opportunity altogether [13]. This period to start a professional career in the work sector, the students must be able to assess their strengths and weaknesses before entering the work. The goal of vocational high school is to prepare students for work after graduation, so there is a development of vocational high school students. According to the Ministerial Education Regulation No. 60 of 2014, Indonesia has developed a vocational high school apprenticeship program that covers the basic framework and structure of the curriculum, especially the development of vocational high school students, as follows:

1. In the school, the vocational high school system can be implemented by a half-semester (about three months) modular system; it can also be accepted for three days a week, 8 hours a day for one semester;

2. In the learning process, subjects A and B (normative and adaptive) can be studied during the apprenticeship, with portfolio evaluation as the primary assessment tool;

3. In the curriculum setting, the vocational high school and the industrial or commercial department arrange a two-system course, systematically integrate the education courses in the school, and the skills acquired through the direct work in the partner institutions to achieve a certain degree of professional expertise (education) Department) Culture and Education, 2014).

At the same time, vocational high school apprenticeship is implemented as a syllabus for industrial learning. The purpose of this practice is to enable students to develop their confidence through the practical use of skills [14]. The development of vocational high school students is usually carried out by adopting a learning block system that is compatible with the sectoral industry. Vocational high school students develop for three years and four years: 
Table 3. Implementation of dual system apprenticeship in vocational high school

\begin{tabular}{|c|c|c|}
\hline \multicolumn{3}{|c|}{3 years of program } \\
\hline 10 grade & \multicolumn{2}{|c|}{ Vocational skills practice in school } \\
\hline 11 grade & $\begin{array}{l}\text { Work competence } \\
\text { practise in school }\end{array}$ & $\begin{array}{l}\text { Product realization } \\
\text { practise at Teaching } \\
\text { Factory in school }\end{array}$ \\
\hline 12 grade & $\begin{array}{l}\text { Apprenticeship in } \\
\text { industry }\end{array}$ & $\begin{array}{l}\text { Career transition for } \\
\text { National Exam and } \\
\text { sertification }\end{array}$ \\
\hline 13 grade & & \\
\hline Month & 0 & 9 \\
\hline
\end{tabular}

\begin{tabular}{|c|c|}
\hline \multicolumn{2}{|c|}{4 years of program } \\
\hline \multicolumn{2}{|c|}{ Vocational skills practice in school } \\
\hline \multicolumn{2}{|c|}{ Work competence practise in school } \\
\hline $\begin{array}{l}\text { Apprenticeship in } \\
\text { industry }\end{array}$ & $\begin{array}{l}\text { Praktik realisasi } \\
\text { produk di Teaching } \\
\text { Factory }\end{array}$ \\
\hline $\begin{array}{l}\text { Apprenticeship in } \\
\text { industry }\end{array}$ & $\begin{array}{l}\text { Career transition for } \\
\text { National Exam and } \\
\text { sertification }\end{array}$ \\
\hline 3 & 9 \\
\hline
\end{tabular}

Vocational high school law in Indonesia has a cooperative educational and cultural identity. The function of the industrial sector is to provide students with apprenticeships, learning, and management. In addition to increasing students' knowledge of the world of work, cooperation between schools and industry is based on willingness and mutual needs. If the industrial sector needs to find a good worker, then the government, the industrial sector, and the school jointly developed the Indonesian Qualifications Framework (KKNI/Kerangka Kualifikasi Nasional Indonesia) to improve the quality of vocational high school students (Education and Culture Strategy Plan, 2015). On the other hand, vocational high school apprenticeships in Indonesia have limitations in terms of equipment and materials, which limits the vocational students. The school has worked hard to improve students' skills, such as working with industry and companies. Students must practice in a company. However, due to various restrictions, student apprenticeship was not implemented as expected. Also, unfortunately, apprentices are usually not prepared or suitable for the job required by the company.

\section{B. Active learning in vocational education and training}

In the context of VET (Vocational Education and Training), active learning connects students to real-life situations. They will encounter in their future jobs. Prince (2004; Cited in Chaul and Cheung 2017) defines active learning as an instructional method that involves some classroom activities that engage students and allow them to form their learning experiences; that is, it is a student-centered approach. Active learning is useful for educators to design their teaching and learning strategies when active learning is adopted [15]. At Creighton university school of medicine, Omaha, USA, a research was conducted on team-based learning in anatomy laboratory for promoting active learning and professionalism with a group of 5-6 students. The groups showed the progress of active learning through active question and answer and increased interaction and involvement of students [16]. It was also found that active learning can be more effective if before group discussion is given short lectures and opened discussions of class before student group activities begin [17]. Active learning is intended to limit the content of learning and the success of discussions in larger groups.

Group discussion in apprenticeship on the industry is outside-class learning that requires interaction among students and instructors. The processes of learning assume a challenging role in a vocational education and training context and collaboration skills. Lee et al. (2015; cited by Motta et al. 2017) define promoting collaborative problem-solving activities in initial VET programs can support not only the development of collaborative skills, but it is also essential to develop professionalism and contribute to the improvement of the quality of apprentices' learning [18]. As shown in Spain, vocational education program director at the workplace using the practice module showed that compulsory placement, school-work alignment, work-based supervision, access to resources, and task complexity are significant moderators between the competencies learned at school and those used at the workplace [19]. It is essential in an 
apprenticeship that students get appropriate support to apply what they have learned at school and make an adjustment to real-life working situations as a part of a learning experience.

In an apprenticeship program in Indonesia, students are not the only passive audience, but also becoming part of the production process mentored by assigned employees. The benefit of an apprenticeship is mutual for both vocational school and the industry. The industry benefits from the assistance of the students since students taking apprentices are students who already have the knowledge, skills, and the attitude required to do an apprenticeship in the industry [20]. Which is a vocational education program that includes theory and practice? That is why it is called a dual system education. Theoretical learning in schools is based on the learning job sheet, followed by periods of work experience in an industry or company. The students complete the job sheet at school then take the required period of work experience in the company or work organization. One of the limitations of apprenticeship is that sometimes students come from various schools, so they have different backgrounds and facilities in their respective schools but are coming to the same place of apprenticeship. So, active learning and collaboration are essential to achievement learning.

The essence of active learning is learning by doing, followed by "actively overcoming gaps in knowledge and skills." These processes include instructive and skill demanding experiences. Other processes are "learning by seeing things in practice" and "preparation and evaluation." Learning outcomes are seen as learning about: working, professional competences, and personal growth. Most of the frequently mentioned in most cases with painful experiences are "professional knowledge and skills," "learning about personal growth," and "learning about working" [21]. Active learning overcomes gaps between knowledge and skills, which refers to as a learning process that occurs with instructive and challenging experiences. Other studies also show that students' active involvement is essential for learning.

Teaching and learning at TVET, by its definition, must consider active learning and practical training as the core of their vocational goals. Also, technical and pedagogical skills are intrinsically related, as a teacher cannot effectively teach technical skills without the pedagogical skills needed to do so [22]. Michael Prince Cited Dickson 2017 showed evidence that several strategies in the active learning approach have proven successful in many domains in adult education. For example, cooperative learning has been shown to improve academic achievement and attitudinal results. Effective teamwork, interpersonal skills, and collaborative learning through group work can improve academic achievement and student attitudes.

\section{Context of Collaboration}

The management of the public sector is essential to serve the need of people. In the mid1990s, the public sector of the central government in many countries gave more authority to lower government officials to run public services directly. This matter required developing partnerships and collaborations between two or more institutions. The types of public sector networks are classified into three types as follows collaboration through the joint decision making and production, involve different agencies negotiating shared goals, and committed to working together for the long term [23]: public sector concern, especially the education sector and health sector. From an individual perspective in an institution, contributions of individuals to institutions are significant for institutions' development. Participating individuals understand that the role will make successful collaboration involving individuals' contributions to the group [24]. It happens because every individual should understand a memorandum of understanding about the collaboration between two institutions in the institutions.

Collaboration can be called a partnership, cooperation, compromise, consensus, and community-building. In the educational sector, a collaboration of a school with other schools shows positive evidence such as improvements in teaching and learning, powerful forms of professional development at all levels, not least that of headteachers, a higher capacity for managing change and implementing innovations, effective induction of newly appointed 
headteachers, and the creation of a more cooperative environment within which external support staff, including those from other agencies, are believed to be able to work more effectively [25]. These requirements of success in managing collaboration in education must be supported by the headmaster, teachers, the involvement in grassroots, focus of resources, time management, and commitment.

The TVET (Technical and Vocational Education and Training) is the education sector working closely with industries. Many memorandums of understandings have been signed between vocational institutions and industry, serving as an indicator of willingness to collaborate. However, few follow up have materialized. In Malaysia, collaborations between TVET agencies and industries are occurring at the various levels of the education sector. The pre-employment skills development as the main objective of collaborations across all levels of education, while research and innovation serve as a second main objective in the higher TVET sectors [26]. The success of collaboration not only can be seen as an achievement, cultural factors in global competition intercultural competence (i.e., understanding and sensitivity toward cultural differences and collaboration across them). On the other hand, the two groups are positively related to each other; as cross-cultural collaborations are indispensable to tackling any global challenges, they do belong to two distinct spheres of knowledge that could roughly be associated with the dynamics of social structures and the cultural foundations of human behavior respectively [27]. The globalization makes student exchange possible, fostering the importance of interpersonal dialogue and academic collaboration between international and domestic students in classes. Collaborations between practitioners and researchers to continually investigate the potential of internationalization efforts on campuses promote students' development of critically critical intercultural skills [28]. Collaboration in learning in global competitions requires students to have autonomous character and be willing to explore, think, read, solve, reflect, and evaluate. On the other hand, independent of learning must be accompanied by collaboration with other students.

Collaboration is a crucial framework mentioned by twenty-first-century skills partnership that needs to be integrated into education. Collaboration is also suited for social constructivist pedagogy as it bases its activity on social interaction as scaffolding to learning [29]. Activity for students can be done in the classroom or outside of the classroom with various collaboration techniques. Collaboration can be done by concentrating more on having the students work with authentic materials, allowing more time for collaboration, facilitating discussion, giving students time to reflect, and creating ways to give students more scaffoldings to build a meaningful learning community [30]. Furthermore, collaboration has in another sector, for instance, STEAM activities. STEAM calls for activities, particularly assessment, using collaboration. Collaboration has some good traits that contribute to the fact that collaboration generates a more effective division of labor, the incorporation of solutions from group members with differing perspectives, knowledge, and experience, and enhanced solution quality by the ideas of other group members [31]. Three sufficient aspects that argue the activity of students in STEAM, outside the classroom, and inside the classroom can include collaboration elements.

Collaboration is becoming increasingly important in the modern world as humans become more connected around the globe. The skill to efficiently solve a problem together with others is of particular importance across educational settings and in the workforce. Collaboration has distinct advantages over individual problem solving from at least two aspects: first, it allows for an active division of labor by incorporating information from multiple sources of knowledge, perspectives, and experiences; second, it enhances creativity and quality of solutions stimulated by ideas of other group members (OECD, 2013) [32]. In a global context, regional or classroom collaboration can be seen as beneficial where communication is needed between two or more parties for coordinating and share responsibility toward cooperation agreement. 
Collaboration can be defined as an agreement between two or more parties at the same agreement in all levels to understand the purpose of collaboration, with factors as a collective responsibility, difference of culture, connectivity, excellent communication, active involvement, building commitment, and coordination.

\section{SIGNIFICANCE AND PURPOSE OF THE STUDY}

In the view of the different literature cited, this study seeks to help the West Java Province vocational education training system reflect on the implementation of the apprenticeship program from students' view of the importance of the contents collaboration for active learning through apprenticeship. This paper is not to address or decide if the collaboration in the apprenticeship program is successful or not. Instead, the result of this research is to describe the collaboration of students in apprenticeship for a specified period.

This study aims to find out the collaboration of students on the apprenticeship program for active learning. Specifically, this research seeks to:

1). Describe the collaboration of students on the apprenticeship related to active learning of vocational school in West Java province.

2 ). This research is expected to give information about the relation of collaboration and active learning in vocational education.

$3)$. This research is expected to give information about the theory the collaboration and active learning in apprenticeship.

\section{METHODS}

Determination sample research through purposive sampling (sample selection) is selection of samples judgment to select a sample that believe, based on prior information, will provide the data research need. ${ }^{1}$ For statistical analysis the determination of the sample size follows the minimum rules in the cluster analysis with a sample size of over 200 students. $^{2}$ Based on working of area and vocational high school from each working area is will select one vocational high school as the First Profession Certification Institution

(LSP P1), except for thirteen working area have not vocational high school as the First Profession Certification Institution with details as follows:

Table Population amount based on the First Profession Certification Institution and The Education Service and Supervision of Regional Education (cabang Dinas)

Table 4. Sampling and location of the study

\begin{tabular}{|c|c|c|}
\hline School & Field Competence & Total \\
\hline $\begin{array}{l}\text { Vocational School of } \\
\text { Cibinong Bogor }\end{array}$ & $\begin{array}{l}\text { Information and } \\
\text { communication }\end{array}$ & 79 \\
\hline $\begin{array}{l}\text { Vocational School Bhakti } \\
\text { Kencana of Subang }\end{array}$ & Health and social work & 75 \\
\hline $\begin{array}{l}\text { Vocational School of } \\
\text { Pacet Cianjur }\end{array}$ & $\begin{array}{l}\text { Agribusiness and } \\
\text { agrotechnology }\end{array}$ & 66 \\
\hline $\begin{array}{l}\text { Vocational school of } \\
\text { Bandung }\end{array}$ & Business and management & 79 \\
\hline $\begin{array}{l}\text { Vocational school of } \\
\text { Mundu Cirebon }\end{array}$ & Maritime & 73 \\
\hline $\begin{array}{l}\text { Vocational school of } \\
\text { Garut }\end{array}$ & $\begin{array}{l}\text { Information and } \\
\text { communication }\end{array}$ & 81 \\
\hline $\begin{array}{l}\text { Vocational school of } \\
\text { Sukabumi City }\end{array}$ & $\begin{array}{l}\text { Technology and } \\
\text { engineering }\end{array}$ & 67 \\
\hline \multicolumn{2}{|c|}{ Total sample } & 520 \\
\hline
\end{tabular}

\footnotetext{
${ }^{1}$ How to design and evaluate research in education. Fraenkel and Wallen. McGraw-Hill International edition, Seventh edition. New York, 2008. p.99

${ }^{2}$ Handbook of Quantitative Methods for Educational Research. DiStefano and Mindrila. Sense Publishers. Rotterdam, 2013. p.107
} 


\section{INSTRUMENT VALIDITY AND RELIABILITY}

This study is quantitative, and a survey method was utilized. The survey questionnaire follows use rating scale to measure the perception of the respondent (student). The rating scale is a choice A (Always), (O) often, $\mathrm{S}$ (sometimes), $\mathrm{E}$ (ever) and $\mathrm{N}$ (never).

\begin{tabular}{lccccc}
\multicolumn{7}{c}{ Table 5. Rating scale } \\
\hline Response & $\mathrm{A}$ & $\mathrm{F}$ & $\mathrm{O}$ & $\mathrm{S}$ & $\mathrm{N}$ \\
Value & 5 & 4 & 3 & 2 & 1 \\
\hline Note: A = Always, F = Frequently, $\mathrm{O}=$ Occasionally, S = Seldom, N = Never
\end{tabular}

The instrument has been tested with 57 people for the collaboration variable consisting of 20 items, obtained 18 valid instrument items. Calculation of validity for the instrument tested using Pearson product-moment correlation and t-test as follows:

Table 6. Indicator instrument

\begin{tabular}{lcc}
\hline \multirow{2}{*}{ Indicator } & \multicolumn{2}{c}{ Number of instrumen } \\
\cline { 2 - 3 } & Positive & Negative \\
\hline Collective responsibility & $1,3,14$ & 17 \\
Cultural difference & 8,10 & 11 \\
Connectivity and good & $2,6,13$ & 5 \\
communication & & \\
Active involvement & 15,18 & 4 \\
Building commitment and & $7,9,12$ & 16 \\
coordination & & \\
\hline \multicolumn{1}{c}{ Total } & 13 & 5 \\
\hline
\end{tabular}

To determine the reliability of the collaboration variable instrument using the formula "Alpha Cronbach". Based on the calculation obtained the reliability coefficient $r_{11}=0.827$ with $r_{\text {table }}=$ 0.266 product moment with $\mathrm{d}_{\mathrm{k}}=\mathrm{n}-1=57-1=56.5 \%$ significance level. The decision by comparing $r_{11}=0.827$ with $r_{\text {table }}=0.266$, then $r_{11}>r_{\text {table }}$ then the instrument of collaboration variable means reliable.

\section{RESULT AND DISCUSSION}

The result of the questionnaire answered with a sample $(n=520)$ of students. The table explains how many percents CHOSE always, frequently, often, seldom and never. The result can be seen in the table:

Table 7. Percentage of indicators

\begin{tabular}{lccccc}
\hline \multicolumn{1}{c}{ Indicator } & $\mathrm{A}$ & $\mathrm{F}$ & $\mathrm{O}$ & $\mathrm{S}$ & $\mathrm{N}$ \\
\hline Collective responsibility & & & & & \\
Work together with colleagues & 38 & 38 & 18 & 5 & 1 \\
Share responsibility and work & 40 & 39 & 15 & 5 & 1 \\
flexible in planning & 13 & 34 & 35 & 15 & 2 \\
influence other to cooperate & 2 & 4 & 39 & 22 & 33 \\
Cultural difference & & & & & \\
Obey general rule & 34 & 38 & 21 & 7 & 1 \\
Comfortable with different team & 4 & 6 & 25 & 17 & 48 \\
I don't receive strength/weak OF & 4 & 6 & 25 & 17 & 49 \\
others & & & & & \\
Connectivity and communication & & & & & \\
Understand instruction of instructor & 32 & 45 & 18 & 4 & 1 \\
Obstacles to contacting mentors & 4 & 9 & 36 & 22 & 30 \\
Barrier in communicating with & 2 & 5 & 18 & 21 & 54 \\
friends & & & & & \\
Have Good speaking (know & 35.2 & 38.2 & 20.2 & 6 & 0.4 \\
audience) & & & & & \\
Active involvement & & & & & \\
Respectful and professional & 48 & 34 & 12 & 5 & 1 \\
Open to new ideas & 21 & 32 & 34 & 9 & 4 \\
Common goal is not priorities & 7 & 13 & 37 & 15 & 28 \\
Building commitment & & & & & \\
Work together with different school & 59 & 31 & 8 & 2 & 0 \\
Easy to coordinate & 23 & 33 & 31 & 9 & 3 \\
Well communicate with instructur & 52 & 37 & 8 & 3 & 1 \\
Integrity with positive ethics & 48 & 37 & 12 & 4 & 1 \\
\hline$\quad$ Note: A = Always, F = Frequently, O = Occasionally, S = Seldom, N = Never
\end{tabular}


The result of the descriptive statistics questionnaire, can be seen in the table below:

Table 8. Statistics descriptive of indicators

\begin{tabular}{|c|c|c|c|c|c|}
\hline Indic ator & $\overline{\boldsymbol{x}}$ & $\Sigma$ & $\mathrm{s}$ & kur & $\mathrm{g}$ \\
\hline \multicolumn{6}{|l|}{ Collective responsibility } \\
\hline Work together with colleagues & 4.06 & 2112 & 0.93 & 0.46 & -0.09 \\
\hline Share responsibility and work & 4.1 & 2134 & 0.93 & 0.58 & -0.97 \\
\hline flexible in planning & 3.41 & 1772 & 0.97 & -0.48 & -0.17 \\
\hline Influence tocooperate & 3.81 & 1981 & 0.99 & -0.72 & -0.24 \\
\hline \multicolumn{6}{|l|}{ Cultural difference } \\
\hline Obey general rule & 3.97 & 2056 & 0.94 & -0.31 & -0.62 \\
\hline Comfortable with different team & 2.02 & 1046 & 1.17 & -0.22 & 0.85 \\
\hline Don't rec eive strength/weak & 4.0 & 2080 & 1.16 & -0.21 & -0.86 \\
\hline \multicolumn{6}{|l|}{ Connectivity and communication } \\
\hline Understand instruction & 4.04 & 2101 & 0.85 & 0.47 & -0.75 \\
\hline Obstacles to contacting mentors & 3.64 & 1894 & 1.11 & -0.65 & -0.32 \\
\hline Barrier communicating with friends & 4.20 & 2185 & 1.02 & 0.35 & -1.09 \\
\hline Good speaking (know audience) & 4.02 & 2090 & 0.91 & 0.28 & -0.64 \\
\hline \multicolumn{6}{|l|}{ Active involvement } \\
\hline Respect and professional & 4.23 & 2198 & 0.92 & 1.09 & -1.20 \\
\hline Open to new ideas & 3.58 & 1860 & 1.04 & -0.30 & -0.37 \\
\hline Common goal is not priorities & 3.45 & 1793 & 1.22 & -0.88 & -0.19 \\
\hline \multicolumn{6}{|l|}{ Building commitment } \\
\hline Work together with different school & 4.48 & 2321 & 0.719 & 1.35 & -1.32 \\
\hline Easy to coordinate & 3.64 & 1881 & 1.043 & -0.34 & -0.43 \\
\hline Well communicate with instructur & 4.37 & 2268 & 0.787 & 2.15 & -1.38 \\
\hline Integrity with positive ethics & 4.27 & 2221 & 0.847 & 1.05 & -1.14 \\
\hline
\end{tabular}

Statistics is a collection of methods that help us describe, summarize, interpret, and analyze data to conclude data vital in research, administration, and education [33]. In this paper, using descriptive statistics to explain the response questionnaire of students with quantitative value. Descriptive statistics involve mean of the "arithmetic average" of a set of scores, to find the mean of these scores, add them up, and then be divided by the number of scores. The standard deviation has the same unit measurement as the data, whereas the unit of the variance is the square of the units of the observations [34]. The index of skewness takes the value zero for a symmetrical distribution. A negative value indicates a negatively skewed distribution, a positive value of a positively skewed distribution. The kurtosis index measures the extent to which the peak of a unimodal frequency distribution departs from the shape of normal distribution [35].

An apprenticeship can define the learning of students outside class to prepare to work in the future. The students in apprenticeship are learning with students from other schools from the same field of competence. They are divided into several teams, which may consist of students from one school or several different schools. The statistics descriptive have to purpose to explain active learning from students' collaboration with several indicators in apprenticeship. Indicator collective responsibility in apprenticeship can be seen work together and share responsibility always about upper $30 \%$ in the answer of the questionnaire, but flexible planning is more visible occasionally. Compelling value -0.97 means students are easy to share responsibility and work.

Indicator of cultural difference; generally, students can obey rules of learning outside of school Receiving strength or weakness of other team members occasionally is more acceptable. In another view, it can be seen that students are not comfortable in learning/working with a different team. Students in apprenticeship have about $45 \%$ frequency for understanding instruction from the instructor; however, Students do not have obstacles in contacting mentors. From the value of kurtosis and skewness, it can be seen that the students have no barrier in communicating with friends.

Indonesia's vocational schools, which have motto skill full and outstanding, are in harmony with respect and professional seeing from indicator of active involvement shown by the questionnaire's value of about $48 \%$. On the other hand, the students have high value for a 
common goal, which is not priorities about $37 \%$. As for the indicator of building commitment and coordination, the students in apprenticeship have value zero for work together with a different school. It is evident on the basis data that an apprenticeship, students learn together with other students from another school.

\section{CONCLUSIONS, LIMITATION AND IMPLICATION}

This paper is not to decide whether active learning of student collaboration in the apprenticeship context in West Java Province has been successful or not. It does not describe students' collaboration with five indicators in Indonesia, especially West Java Province, for vocational school as a research sample. Based on the literature review on active learning and students centered approach to the belief that active learning can promote team-based learning (collaboration).

Data questionnaire shows that students in apprenticeship percentage are always more $30 \%$ $(n=520)$ as follows: Share responsibility and work is related with the task in apprenticeship, obey general rule in apprenticeship is related with discipline, communication with instructor is well related with design teaching-learning strategies for the educator. Generally, student respect and professionalism are related to active involvement. Last but not least, Indonesia students of vocational schools have integrity with positive ethics. These findings answer what this research seeks to describe and give information about the relation of students' collaboration and active learning.

This research certainly has limitations, as well as some implications. As this research is conducted in West Java Province for vocational schools selected by the first professional certification institution, the result and analysis accurately reflect from the questionnaire and student perceptions. On the other hand, this research serves only as a quantitative analysis and statistics description. It investigates student collaboration for active learning at vocational education and training in an apprenticeship with indicators, namely the collective responsibility of students and instructors, cultural difference appreciation, skills communication, and commitment building. Researcher sees that the indicator of active involvement learning and training must be improved along with professionalism and positive ethics.

\section{FURTHER RESEARCH}

We found from statistics descriptive that student collaboration for active learning in apprenticeship is essential because it allows learning and training outside the school with other students from different schools. This study has a limitation that it is only quantitative research. Future active research is advised to explore more through a qualitative approach and researching teacher and instructor perspectives in vocational education and training.

\section{REFERENCES}

[1] Andreas Schleicher, "Review of National Policies for Education (Education in Indonesia, Rising to the challenge) OECD," ADB. OECD "Better Policies For Better Lives" 2015. p.64.

[2] The Minister of Finance Republic of Indonesia, "Indonesia's Intergovernmental Transfer Response on Future Demographic and Urbanization Shifts Improving the Policy Framework for Fiscal Decentralisation (the Grand Design of Fiscal Decentralization)," November 2011. p.2.

[3] Instruksi Presiden Republik Indonesia, Nomor 9 tahun 2016 tentang, "Revitalisasi SMK dalam rangka meningkatkan kualitas dan daya saing sumber daya manusia Indonesia," Jakarta 2016. p. 1-2. 
[4] Baller S et.al, "The Global Information Technology Report 2016 (Innovating in the Digital Economy)," World Economic Forum, Geneva 2016. p.16-20.

[5] ASEAN Secretariat, "Roadmap for an ASEAN Community 2009-2015, ASEAN SocioCultural Community Blueprint.” Jakarta, April 2009. p.67-68.

[6] ASEAN Secretariat, “ASEAN Economic community blueprint 2025," Jakarta, November 2015. hal.10.

[7] Devezas T et.al, "Industry 4.0 Entrepreneurship and Structural Change in the New Digital Landscape," Springer International Publishing AG, Switzerland 2017. p.1-2.

[8] Griffin P et al, "The Changing Role of Education and Schoo, Assessment and Teaching of 21 st Century Skills,” Springer Science+Business Media B.V, New York 2012. p.3.

[9] Direktorat Jenderal Pendidikan Dasar dan Menengah Kementerian Pendidikan dan Kebudayaan Republik Indonesia, "SMK dari masa ke masa," Jakarta, Desember 2015. p.114-116.

[10] BPS RI, "Statistik Indonesia Badan Population and Employement," Jakarta Juni 2017. p.80-93.

[11] Kemdikbud, "http://psmk.kemdikbud.go.id/datapokok," Accessed 13 January 2018, $03.50 \mathrm{pm}$.

[12] E. Kosasih Danasasmita. Teachers' skills development model in the evaluation of competency-based student learning outcomes in vocational schools in Indonesia. Indonesia University of Education (UPI), Bandung,. 2011. p.175

[13] Clemens Wieland. Situated Competence Development through Innovative Apprenticeships The Role Of Different Stakeholders. Bertelsmann Foundation. Preface Conference Proceedings, International Network on Innovative Apprenticeship (INAP). Vienna, Austria. 2008. p.11-12

[14] Revitalisasi Pendidikan Vokasi. Hendarman, Kementerian Pendidikan dan Kebudayaan Republik Indonesia. Jakarta. 2016. page.54

[15] S. Chaul and C. Cheung, "Bringing Life to Learning"': A Study of Active Learning in Hospitality Education," Ó De La Salle University, 20 April 2017. pp.127-136.

[16] K.N. Huggett, M. D. White, F. Knoop, C.A. Eno, and D.M. Cullen, "Team based learning in anatomy lab: Promoting active learning and professionalism," Creighton University School of Medicine, Omaha, NE, USA, 9 November 2015. p.5.

[17] D. Lee, A.S. Morrone, and G. Siering, "From swimming pool to collaborative learning studio: Pedagogy, space, and technology in a large active learning classroom," Emporia State University, 20 December 2017. p.95.

[18] E. Motta, A Cattaneo, and J.L. Gurtner, "Co regulations of learning in small groups of chef apprentices: when do they appear and what influences them?," Swiss Federal Institute for Vocational Education and Training, 24 Agustus 2017. p.1-18.

[19] A.I.R Davids, P.V. Bossche, D Gijbels, and M.F. Garrido, "The Impact of Individual, Educational, and Workplace Factors on the Transfer of School-Based Learning into the Workplace," Tarragona, Spain Department of Pedagogy, 29 December 2016. pp.275293.

[20] Hendarman, "Revitalisasi Pendidikan Vokasi. Kementerian Pendidikan dan Kebudayaan Republik Indonesia,” Jakarta. 2016. p.31.

[21] A. Wagenaar, A.J.J.A. Scherpbier, H.P.A. Boshuizen, and V.D. Vleuten, "The Importance of Active Involvement in Learning: A Qualitative Study on Learning Results and 
Learning Processes in Different Traineeships," Faculty of Medicine, Maastricht, The Netherlands, 2003. pp. 201-212.

[22] M Dickson, and S.E. Ladefoged, " Introducing active learning pedagogy into a technical and vocational education and training academy in Kurdistan, Iraq," Emirates College for Advanced Education, Abu Dhabi, UAE, 23 August 2017. pp. 679-699.

[23] D. Muijs et al, "Networking and Collaboration as a Public Policy Framework," Springer Dordrecht Heidelberg London New York. 2011. p.9-12.

[24] Margaret Weige et al, "New Digital Media and Their Potential Cognitive Impact on Youth Learning," Springer Science+Business Media. Harvard University, Project Zero, Cambridge. 2010. p.40.

[25] D. Muijs et al, "Achieving Excellence and Equity: Reflections on the Development of Practices in One Local District Over 10 Years," Collaboration and Networking in Education London New York. 2011. p.98.

[26] Maizam Alias and Razali Hassan, "TVET Agency-Industry Collaborations: Addressing Diversity, Indonesia, 2nd UPI International Conference on TVET," Universiti Tun Hussein Onn Malaysia. 2012. p.111-113.

[27] Elena Galinova, "Promoting holistic global citizenship in College, Implications for Education Practitioners," Sense Publishers. 2015. p.25.

[28] Krista M. Soria, "Institutional and instructional techniques to promote undergraduates intercultural development, Evidence from a Multi-Institutional Student Survey," Sense Publishers. 2015. p.56.

[29] M. Iinuma, "Digital Content, Literacy, and Learning, Springer Briefs in Education," Springer International Publishing Switzerland 2016. p.63.

[30] M. Iinuma, "Technology and Knowledge in the Classroom, Springer Briefs in Education," Springer International Publishing Switzerland 2016. p.21-22.

[31] Danielle Herro et al, "Co-Measure: developing an assessment for student collaboration in STEAM activities," College of Education, Clemson University, USA. 2017. p.2-3.

[32] Collaborative Problem Solving Measures in the Programme for International Student Assessment. Springer.Qiwei He et al. Educational Testing Service, Princeton, Pittsburgh, USA. p. 108

[33] Christian Heumann and Michael Schomaker Shalabh, Introduction to Statistics and Data Analysis, Universität München Germany. 2016. p.3-9.

[34] Homas J. Quirk, Excel 2016 in Applied Statistics for High School Students: A Guide to Solving Practical Problems. Webster University, St. Louis, MO, USA. 2018. p. 2-4.

[35] Sabine Landau and Brian S. Everitt, "Data Description and Simple Inference for Continuous Data: Description of Data" A Handbook of Statistical Analyses using SPSS Chapman \& Hall, London 2004. p. 46-48. 